Литовченко Г. Д.

(0000-0002-8625-1438)

Центр воєнно-стратегічних досліджень Національного університету оборони України імені Івана Черняховського, Київ

\title{
Аналіз процесів управління інформаційним забезпеченням інформаційних систем у сфері управління оборонними ресурсами
}

Резюме. У статті проаналізовано підхід Business Information Services Library (бібліотеки найкращих практик управління інформаційним забезпеченням) щодо його застосування для інформаційного забезпечення інформаційних систем стратегічного управління оборонними ресурсами. Визначено процеси формування інформаційної політики i специфікації вимог до інформаційного забезпечення функціональних процесів управління оборонними ресурсами.

Ключові слова: управління оборонним ресурсами; інформаційна система; інформаційне забезпечення; функціональні процеси; функціональні сервіси.

Постановка проблеми. В умовах високої багатоаспектності та складності завдань, які стоять на сьогодні перед Збройними Силами (ЗС) України, важливим стає забезпечення розроблення, впровадження i використання інформаційних технологій (IT), починаючи 3 постановки цілей, визначення джерел отримання інформації до застосування математичних засобів інформаційно-аналітичної підтримки у сфері стратегічного управління оборонними ресурсами. Під управлінням оборонними ресурсами розуміють специфічну форму адміністративно-господарської діяльності 3С України, а саме підтримку процесів оборонного та мобілізаційного планування, матеріально-технічного, медичного та інших видів забезпечення, управління фінансовоекономічною діяльністю, особовим складом, організаційною структурою, майном, закупівлями, іншими видами адміністративної діяльності [1].

Нині у ЗС України за кожним з напрямів управління оборонними ресурсами створені окремі компоненти інформаційної інфраструктури та інформаційних систем (IC), але вони є різнорідними за часом створення, ступенем завершеності, використаними технологіями, обсягом охоплення процесів, обсягом розгортання та наповнення даними [2]. Зважаючи на це, вдосконалення системи управління оборонними ресурсами та стрімкий розвиток новітніх інформаційних технологій потребують застосування нових підходів як до побудови IC управління оборонними ресурсами, так і до управління їх інформаційним забезпеченням. До того ж nid інформаційним забезпеченням розуміються такі представлення та організація інформації, які відповідатимуть потребам користувачів IC та вимогам автоматизованої обробки даних. Під управлінням інформачійним забезпеченням розуміють наявність чітких процесів руху інформації від моменту іiі створення до використання, застосування систем класифікації та кодування, створення інформаційно-логічних моделей масивів інформації, управління змінами наявних IC, рішення рутинних завдань щодо якості функціонування IC тощо.

Контроль відповідності наданої інформації до потреб користувачів $\epsilon$ ключовою функцією управління інформаційним забезпеченням. Інша важлива функція полягає в наданні технологій, на базі яких узгоджуються інтереси всіх сторін, залучених в інформаційну діяльність. Складність управління інформаційним забезпеченням у сфері управлінням оборонними ресурсами визначається постійними змінами функціонального середовища, появою нових цілей i пошуку нових рішень. Зміни в функціональному середовищі потребують зміни процесів управління для забезпечення відповідності новим вимогам множини учасників, що залучені до створення i використання інформаційних ресурсів. Отже аналіз процесів управління інформаційним забезпеченням щодо їх застосування для IC управління оборонними ресурсами є актуальною задачею.

Аналіз останніх досліджень i публікацій. У роботі [2] розглядаються сучасна методологія i передові підходи до створення IC в оборонному секторі. Роботи $[3,4]$ присвячені основним засадам побудови єдиної інформаційної системи управління оборонними ресурсами. У працях [5-7] висвітлено особливості управління функціональними сервісами IC. Незважаючи 
на певні досягнення у цій сфері, дослідження $\epsilon$ фрагментарними, вирішення питань ефективності функціонування IC управління оборонними ресурсами обмежене, не приділена належна увага вимогам до процесів управління інформаційним забезпеченням.

Метою статі $\epsilon$ аналіз сучасних підходів управління інформаційним забезпеченням інформаційних систем щодо застосування у сфері управління оборонними ресурсами.

Виклад основного матеріалу. 3 наведеного аналізу тенденцій інформатизації у сфері управління оборонними ресурсами можна дійти висновку, що управління, контроль і зміна інформації з погляду попиту на неї $є$ критичними факторами успіху, які показують, наскільки добре інформаційне забезпечення відповідає потребам користувачів i вимогам автоматизованої обробки даних. Важливо управляти інформаційним забезпеченням таким чином, щоб воно повністю відповідало існуючим функціональним процесам управління оборонними ресурсами. Вибудовування цієї відповідності може бути успішним лише тоді, коли різні рівні управління інформаційним забезпеченням сходяться i взаємно пов'язуються.

\section{Основні}

ефективної

інформаційним розділити таким чином:

управління стратегічними і тактичними запитами щодо потреб в інформаційному забезпеченні IC;

управління портфелем проєктів щодо створення нових IC;

управління програмним офісом, тобто певною множиною IC;

управління рутинними операціями щодо підтримки функціонування IC.

На сьогодні у світовій практиці у сфері управління інформаційним забезпеченням використовують такі відомі методологічні підходи, як збірник найкращих практик управління інформаційним забезпеченням (ITменеджменту) - бібліотека сервісів бізнесінформації BISL (Business Information Services Library) [8].

Згідно з підходами, визначеними у BISL, управління попитом на інформацію, перетвореним у вимоги до інформаційного забезпечення, може бути успішним тоді, коли споживачі інформації і ті хто іï надає розділені відносно інформаційного забезпечення. Сторона споживача управляе попитом на інформацію через трансляцію вибору, зробленого на стороні попиту, на вимоги до інформації на стороні пропозиції. Далі фактична послуга надається третьою стороною - постачальником IT-сервісів або відповідним підрозділом.

Інформаційне забезпечення $\epsilon$ важливим для підтримання функціональних процесів. 3 огляду на те, що інформаційне забезпечення важливе, насамперед, для функціональних процесів, контроль над ними має здійснювати не тільки постачальник IT-сервісів. Цей контроль має взяти на себе сторона споживача ІТ-сервісів.

Управління інформаційним забезпеченням, визначення вимог до інформації потребує спеціальних знань i досвіду в роботі 3 функціональними процесами, який відрізняється від технічного досвіду у сфері IT. Управління інформацією $з$ боку управляючого функціональним процесом (менеджера або адміністратора функціонального процесу) забезпечує підтримання функціонального процесу в оптимальному режимі.

Отже, управління інформаційним забезпеченням впливає на процеси проєктування i надання IT-сервісів. Ця діяльність потребує, щоб управління інформаційним забезпеченням було невід'ємною частиною діяльності сторони споживачів ІТ-сервісів.

На управління інформаційним забезпеченням впливають чотири чинники: інформаційне забезпечення функціональних процесів у частині визначення вимог до інформації; автоматизоване інформаційне забезпечення та IT-підтримка в частині процедури замовлення IT-сервісів і моніторинг їх якості;

організаційні заходи щодо управління IT-сервісами - функція, яка безпосередньо управляє інформаційним забезпеченням; політика щодо інформаційного забезпечення.

Важливою передумовою ефективного управління інформаційним забезпеченням $\epsilon$ спеціалізоване знання функціональних процесів, яке досягається різними способами. Оскільки неможливо, щоб одна посадова особа мала усі необхідні спеціальні знання, персонал необхідно поділяти на різні інформаційні групи або галузі знань.

Інформаційне забезпечення в рамках організації можна розглядати на трьох рівнях. Управління інформаційним забезпеченням відбувається на кожному з цих рівнів. 
На корпоративному рівні інформаційне забезпечення управляється в межах всієї організації. Беруться до уваги зв'язки між різними функціональними процесами i ïx вплив на інформаційне забезпечення. На практиці за цим рівнем стежать окремі підрозділи у межах організації, оскільки тут необхідні спеціальні знання, навички та контакти.

На рівні функциіонального процесу відбувається управління всім інформаційним забезпеченням, яке підтримує цей процес. На цьому рівні основними $є$ вимоги до інформаційного забезпечення, які висуваються окремими функціональними процесами.

На системному рівні передбачаються специфічні вимоги користувачів до роботи IC. Інформаційні системи часто підтримують тільки частину функціонального процесу, i навпаки, єдина інформаційна система часто використовується для підтримки декількох функціональних процесів. Це означає, що можуть існувати кілька IC, що підтримують функціональний процес загалом, що зі свого боку може призвести до необхідності управління інформаційним забезпеченням на системному рівні.

Таким чином, сфера відповідальності щодо управління інформаційним забезпеченням $є$ досить широкою. Управління має інтерпретуватися ширше, ніж просто роль операційного адміністратора функціонального процесу. У рамках BISL визначені три рівні:

операційний;

управлінський;

стратегічний.

Зазвичай ролі, які відповідають цим рівням, визначаються адміністраторами функціональних процесів і власниками системи.

Операційний рівень процесів управління відповідає за використання інформаційного забезпечення та визначає вимоги, яким воно має задовольняти. На практиці сюди включаються завдання, які виконуються адміністраторами функціональних процесів.

Управлінський рівень відповідає за витрати, повернення інвестицій, ведення договорів i планування. Власник системи, замовник, власник бюджету тощо відповідають за зазначену сферу діяльності. У разі, коли постачальники IC також управляють інформаційним забезпеченням, цей рівень переводиться в зону їх відповідальності.

Стратегічний рівень стосується майбутнього інформаційного забезпечення. За цей рівень відповідає керівництво вищого рівня.

Відповідна такому розподілу модель управління інформаційним забезпеченням визначає сім груп процесів (рис. 1).

\section{Стратегічний}

Розпорядник системи

\section{5. Група процесів інформаційної стратегії}

7. Зв'язувальні процеси
6. Група процесів стратегії розвитку організації

\section{Управлінський}

Власник системи

\section{4. Група управлінських процесів}

\section{Операційний}

Ключовий користувач

(адміністратор

функціонального процесу)
3.

Зв'язувальні процеси
2. Група процесів управління

фрункціональними

можливостями

Рис. 1. Рівні управління інформаційним забезпеченням

Група процесів 1 - управління використанням - спрямовані на безперервне підтримання інформаційного забезпечення. Ці процеси надають підтримку користувачам щодо інформаційного забезпечення для здійснення діяльності в межах функціонального процесу, операційного управління постачальниками IT-сервісів, а також забезпечують і здійснюють моніторинг своєчасності надання даних. 
Група прочесів 2 - управління функціональними можливостями - описують рівень, на якому відбувається проєктування i реалізація інформаційного забезпечення. Мета цієї групи полягає в здійсненні змін таким чином, щоб вони вписувалися в набір структур i вимог та одночасно 3 цим задовольняли цілі функціональних процесів $\mathrm{i}$ запити користувачів.

Група процесів 3 - зв'язувальні процеси операційного рівня - пов'язують між собою групи процесів управління використанням i управління функціональними можливостями, які не можуть функціонувати окремо. Метою цих взаємодіючих процесів $\epsilon$ прийняття рішеннь щодо необхідних змін в інформаційному забезпеченні та якою має бути фактична реалізація цих змін.

Група процесів 4 - управлінських процеси - забезпечує інтегральне управління згаданими групами процесів. Управлінські процеси здійснюють моніторинг діяльності щодо узгоджених витрат, вимог, договорів та планування.

Група процесів 5- інформаційної стратегії - відповідає за розроблення майбутньої стратегію інформаційного забезпечення. Як безпосередньо в самій організації, так і у функціональних процесах постійно відбуваються різного роду зміни, які впливають на потреби щодо інформаційного забезпечення. Важливо, щоб інформаційне забезпечення відповідало майбутнім вимогам, а структурні недоліки поточної ситуації були вирішені.

Група процесів 6 - стратегії розвитку організації - координує управління, структурування методів роботи, прийняття рішень у сфері інформаційного забезпечення. Це може бути застосовано до відносин зі сторонами, що знаходяться поза межами управління інформаційним забезпеченням, такими як IT-постачальники і споживачі.

Група прочесів 7 - зв'язувальні процеси стратегічного рівня - пов'язують між собою зміст (група процесів 5) і стратегією розвитку (група процесів 6).

Висновки. Отже, підходи BISL на практиці доцільно використовувати для створення єдиної інформаційної системи управління оборонними ресурсами. Їх успішне застосування значною мірою визначається зв'язками між різними групами і різними рівнями процесів управління інформаційним забезпеченням. До того ж забезпечується взаємодія та комунікація між визначеними групами процесів управління, що $\epsilon$ вирішальними факторами створення ефективної інформаційної інфраструктури МO України i якості інформаційного забезпечення функціональних процесів у сфері управління оборонними ресурсами.

$$
\text { у сучасних умовах складність }
$$

інформаційних систем сфери оборони зростає, а методи і технології ефективного управління інформаційним забезпеченням динамічно розвиваються. $\mathbf{У}$ подальших дослідженнях доцільно розглянути нові архітектурні підходи до побудови програмних платформ IC стратегічного управління оборонними ресурсами, орієнтованих на надання відповідних функціональних сервісів.

\section{СПИСОК ВИКОРИСТАНОЇ ЛІТЕРАТУРИ}

1. Романченко I. С., Богданович В. Ю., Дєнєжкін М. М. Теоретико-методологічні засади побудови системи управління ефективністю планування та виконання програм розвитку Збройних Сил України. Наука і оборона. 2015. № 3/4. C. 50-55.

2. Кірпічніков Ю. А., Утюшев М. К., Закалад М. А. Аналіз світового досвіду застосування інтеграційних технологій в автоматизованих системах управління. Збірник наукових пращь Центру воснно-стратегічних досліджень Національного університету оборони України імені Івана Черняховського. Київ, 2016. № 3 (58). C. 131-135.

3. Кірпічніков Ю. А., Головченко О. В., Петрушен М. В. Визначення технологічних рішень щодо створення єдиної інформаційної системи управління оборонними ресурсами. Збірник наукових праиьь Центру воєнно-стратегічних досліджень Національного університету оборони України імені Івана Черняховського. Київ, 2019. № 1(65). С. 86-91.

4. Кірпічніков Ю. А., Петрушен М. В., Васюхно С. I. Теоретичні підходи до побудови архітектури інформаційної системи управління оборонними ресурсами на основі сервісно-орієнтованої моделі. Збірник наукових праиь Центру воєнно-стратегічних досліджень Наиіонального університету оборони України імені Івана Черняховського. Київ, 2018. № 1 (62). C. 80-85.

5. Беляченко В. В., Педан Ф. П., Романченко О. А. Підходи до створення, підтримки i вдосконалення АСУ логістичного забезпечення ЗС України з урахуванням досвіду країн - членів НАТО. Збірник наукових пращь Центру воєнностратегічних досліджень Національного університету оброни Украӥни імені Івана Черняховського. Київ, 2018. № 3 (64). С. 54-60.

6. Головін О. О. Сдиний інформаційний простір основа ефективної реалізації принципів програмно-цільового планування розвитку озброєння та військової техніки. Наука і техніка 
Повітряних Сил Збройних Сил Украӥни. Харків, 2018. № 2 (31). С. 41-46.

7. Долженко А. И. Управление информационными системами : курс лекций. Ростов-на-Дону, 2007. $191 \mathrm{c}$.
8. Ван дер Полс Р., Донац Р., Ван Аутфорст Ф. BiSL. Сборник описаний процессов для управления бизнес-информацией. Москва : 2014. $191 \mathrm{c}$.

Стаття надійшла до редакційної колегії 01.02.2021

\section{Analysis of information management processes for information systems in the field of defense resource management}

\section{Annotation}

At present time in the Armed Forces of Ukraine have already created separate components of information infrastructure and information systems in each of the areas of defense resources management. But these components are heterogeneous in time of creation, degree of completion, technologies used, scope of processes, volume of deployment and data filling.

Therefore, the improvement of the defense resources management system and the rapid development of technology require new approaches, both to the construction of information systems for the management of defense resources, and to their information support.

Information support in this paper means the presentation and organization of information that meets the needs of users of information systems and the requirements of automated data processing. Therefore, the analysis of management processes of information support of information systems of defense resources management remains an urgent task for today.

The information management model defines seven groups of processes:

management of the use of information support;

functionality management;

operational level binding processes;

management processes;

information strategies;

organizational development strategies;

strategic-level linking processes.

Management of information support should take place in such a way that it fully corresponds to the existing functional processes of defense resources management. Building such a match can only be successful when the different levels of information management converge and interconnect.

Keywords: sphere of defense; defense resource management; information system; information support; functional processes; functional services. 